\title{
Gravura popular brasileira
}

Peter Burke*

Tradução do inglês de João Adolfo Hansen

RAMOS, Everardo. Du marché au marchand. La gravure populaire brésilienne. Gravelines: Musée du Dessin et de l'Estampe Originale, 2005. 191 p.

2005 foi comemorado na França como "o Ano do Brasil” e as comemorações incluíram uma exposição de gravuras brasileiras no Musée du Dessin et de l'Estampe Originale de Gravelines, da qual este livro é o catálogo. Seu autor, Everardo Ramos, terminou recentemente uma tese de doutoramento sobre o mesmo assunto na Universidade de Paris X e com certeza dá uma contribuição original ao conhecimento. Seu ensaio-catálogo é organizado cronologicamente e dividido em três fases principais: “origens”, entre 1800-1860; a era dos livrinhos vendidos por ambulantes, que os brasileiros chamam de folhetos ou literatura de cordel, entre 1860-1950; e, finalmente, o último meio século, o tempo da passagem "da praça do mercado ao negociante" que deu título à exposição e ao ensaio.

Na primeira parte de seu ensaio, Ramos faz uma discussão inovadora de uma tópica negligenciada. Como observa, no Brasil, diferentemente da América Espanhola, nenhuma máquina impressora foi permitida antes de 1808. Depois deste ano, a imprensa foi estabelecida não só no Rio, mas também nas cidades maiores do Nordeste, Salvador e Recife. Periódicos produzidos no Recife e em outras partes tiveram papel importante nos debates ocorridos antes, durante e depois da independência do Brasil.

Historiadores têm estudado a imprensa brasileira do início do século XIX, mas, até Ramos, deram pouca atenção às xilogravuras que ilustraram jornais como $O$ Marimbondo ou $O$ Arara. Seus elogios da qualidade artística dessas xilogravuras podem ser meio exagerados, mas é convincente seu argumento de que reforçaram com intensidade as mensagens políticas freqüentemente polêmicas dos jornais. Com efeito, para o público iletrado, que era maioria mesmo nas cidades, as imagens eram as mensagens.

* professor no Emmanuel College, Universidade de Cambridge. 
A parte principal do ensaio de Ramos, de maneira bastante razoável, trata dos folhetos brasileiros que floresceram muito mais tarde que seus congêneres europeus, especialmente entre 1900 e cerca de 1960, embora ainda hoje estejam sendo produzidos. Os folhetos são livrinhos baratos escritos em verso, tratando de um amplo elenco de temas, dos feitos de bandidos como Lampião ou de poetas populares que se desafiam uns aos outros a improvisar versos aos problemas da inflação e da AIDS. Esses livrinhos foram originalmente produzidos em tiragens reduzidas em pequenas prensas por poetas populares que geralmente recitavam ou cantavam suas obras em feiras antes de vender cópias deles para o público (incluindo iletrados, que habitualmente podiam contar com alguém que lia o texto quando pediam). A maior parte dos textos eram produzidos e consumidos no Nordeste do Brasil, a região mais pobre do país com o mais baixo nível de alfabetização, sem eletricidade nas áreas rurais até os anos de 1980 e, assim, não alcançada pela TV. Dos anos 1950 em diante, contudo, os folhetos foram sendo crescentemente produzidos em massa, especialmente em São Paulo, não só devido ao número crescente de migrantes nordestinos, mas também devido à distribuição por todo o Brasil. Mais de 200 mil cópias de um folheto descrevendo o suicídio do Presidente Getúlio Vargas em 1954 foram impressas.

Há uma ampla literatura secundária sobre folhetos e a maioria dela data do declínio do gênero dos anos 1960 em diante, frente à competição da TV, cassetes e DVDs, ilustrando assim o que Michel de Certeau chamou de "a beleza da morte". Contudo, como Ramos diz bem, quando examina essas ilustrações da perspectiva de um historiador da arte, os estudiosos tenderam a dar muito mais atenção aos textos que às imagens das capas. Quando os primeiros estudiosos discutiram as ilustrações, concentraram-se nas xilogravuras feitas à moda antiga, ao passo que Ramos dá igual atenção a outros media, principalmente zincogravuras e fotogravuras (ambas encontráveis cedo, por volta dos anos 1910). Também nota a crescente importância, nos anos 1950, das capas produzidas pelo processo de três cores. Compara e contrasta artistas autodidatas com os que aprenderam seu ofício trabalhando em jornais e observa os muitos empréstimos da linguagem visual de cartões-postais, filmes, cartazes e revistas em quadrinhos.

Nesse breve ensaio, Ramos tem pouco a dizer sobre seu conceito central de "gravura popular", embora pareça seguir a sugestão do historiador francês Roger Chartier de que deveríamos usar o adjetivo "popular" para descrever os usos de artefatos mais que textos ou imagens particulares. No entanto, Ramos demonstra estar bem ciente do paradoxo nuclear desse 
gênero. De um lado, intelectuais e turistas - que agora constituem uma parte importante da demanda de folhetos - apreciam esses artefatos por suas qualidades arcaicas, acreditando que fazem parte de um mundo rural virtualmente imutável. De outro lado, editores urbanos e também as pessoas comuns que compram folhetos consideram-nos modernos, preferindo fotografias a xilogravuras. Existe, assim, um sentido pelo qual as ilustrações modernas são mais autênticas ou pelo menos mais "populares" que as arcaicas.

Outra grande mudança tanto nos textos quanto nas imagens poderia ser descrita como "individualização". Como os trovadores da Europa, os poetas populares brasileiros inventaram e ainda inventam tendo por matéria um repertório oral, mas, como outros poetas de hoje, assinam suas obras. As imagens, como Ramos demonstra, muitas vezes eram adaptações de imagens mais antigas e eram freqüentemente recicladas, empregadas por diversos editores e também para ilustrar textos bastante diferentes. Do mesmo modo, os artistas que ele discute freqüentemente assinavam essas obras.

Dada essa tendência para a individualização assim como o interesse crescente pelos folhetos tradicionais demonstrado por um público de classe média e mesmo estrangeiro, foi virtualmente inevitável que as ilustrações xilogravadas se tornassem um gênero independente, vendido para colecionadores e museus, sendo apreciadas como obras de arte de artistas que vêm obtendo reputação internacional. Esse processo é o tema tratado por Ramos no último capítulo e explica o título do catálogo, Du marché au marchand, por outras palavras, a transferência da praça do mercado, onde os poetas declamavam seus versos antes de vender as cópias impressas deles, para os negociantes das galerias de arte. Ele está bem consciente do nexo existente entre o crescente interesse de classe média pelas xilogravuras e o que tem sido chamado de "invenção do Nordeste", o movimento regionalista que enfatizou os bens culturais dessa parte relativamente pobre do Brasil, sua arte, seu folclore e festejos. Assim, o folclorista Theo Brandão e o escritor regionalista Ariano Suassuna foram dos primeiros, por volta dos anos 1950, a chamar a atenção para as ilustrações dos folhetos. No início dos anos 1960, as xilogravuras brasileiras eram suficientemente conhecidas no cenário internacional para serem objeto de exposições em Paris, Barcelona e Basiléia. Um dos mais bem sucedidos e talentosos desses artistas, José Borges, agora vende sua obra através de uma galeria de Zurique, embora continue sendo possível comprar gravuras dele e de membros de sua família na sua oficina na cidadezinha de Bezerros, em Pernambuco (fiquei contente de poder fazê-lo em 2002). Esse sucesso tem seu preço, 
como o artista Amaro Francisco lamenta nessas páginas. 0 que o mercado procura é algo que pareça primitivo e, quando o artista produz uma obra de estilo diferente, o negociante pode recusá-la. A família Borges parece ser sábia ao restringir-se a temas tradicionais da cultura popular do Nordeste, como carnavais, feiras, santos, o profeta local, Antônio Conselheiro, e o rei dos bandidos, Lampião.

Brasileiro vivendo na França e escrevendo para um público francês durante o que foi para eles "l'Année du Brésil", Ramos deu a seu ensaio uma dimensão comparativa, focalizando em particular as imagens de cordéis franceses dos séculos XVII e XVIII, a assim chamada "Bibliothèque Bleue" de Troyes, simples xilogravuras que, como ocorre no caso dos folhetos, eram freqüentemente recicladas para ilustrar histórias diferentes. 0 autor tem pouco a dizer sobre conexões. Ele menciona de passagem fotos de estrelas de Hollywood, como Hedy Lamarr, que foram usadas como ilustrações, transformadas ou não em xilogravuras. Duas dessas ilustrações podem ser suficientes para sugerir outras conexões que valeria a pena continuar estudando. A mulher na capa de uma história publicada por volta de 1910 (figura 47) parece ter saído de um dos cartazes de Toulouse Lautrec. Poderia o artista anônimo ter tido familiaridade com a obra de seu colega francês? 0 segundo exemplo vem de 2005. Uma xilo recente de José Costa Leite, que mostra quatro versões do mesmo casal (p.150), certamente foi inspirada pela famosa imagem de Marilyn Monroe feita por Warhol. 0 Nordeste do Brasil pode ainda ser um mundo fechado nele mesmo, mas não é hermeticamente selado.

Este resenhista só lamenta duas coisas. É pena que esse ensaio pioneiro e penetrante não seja mais extenso; e, pena maior, que só tenha tido 700 cópias. Deve-se esperar que uma versão em português de $D u$ marché au marchand logo apareça no Brasil. 